\title{
System Restructuring as a Factor of Increasing Management Efficiency in Construction
}

\author{
Aida Makhmudovna Esetova, Elena Ivanovna Pavliuchenko, Chanée Tagirovna Ismailova, \\ Timur Yuryevich Levitsky
}

Dagestan State Technical University, Russia; ${ }^{*}$ monblan.pro@yandex.ru

\begin{abstract}
The article substantiates the objective necessity to restructure construction enterprises due to the physical and moral deterioration of a part of assets; high production costs, lack of financing, high risks of investment projects. It systematizes and itemizes the organizational and economic mechanism of restructuring taking into account the peculiarities of a construction enterprise. The author applies a programmatic approach to the implementation of the strategy and tactics of restructuring, which is taken as a basis for the developed plan of preventive measures in a construction enterprise. In order to achieve the agreed actions of administration, managers and stakeholders for restructuring of the construction enterprise, alternative cross-functional solutions of arising problems are allocated. The author proposes a modular approach to management of the business processes of a construction enterprise and proves the importance of formed managerial decision-making system for effective restructuring.
\end{abstract}

Keywords: Business Processes, Construction Enterprise, Management Efficiency, Organizational and Economic Mechanism, Restructuring, Strategy

\section{Introduction}

Improving the efficiency of construction enterprise management includes a variety of tasks. The main ones relate to the clarification of the concept of management, reorganization of management processes in the enterprise and reorganization of organizational structures in the direction of self-administration and entrepreneurship, integration of strategic planning and operational management, strengthening of individual responsibility, awareness and motivation of employees for automation of operations and processes. At the present time, priority should be given to the institutional reforming of the construction enterprises, i.e. improvement of external infrastructure and in-house institutions. The majority of experts in the field of management agree that the objective process of institutional reforming of a construction enterprise in terms of improvement of external infrastructure is restructuring, and managers must be prepared to conduct relevant activities and measures and, subsequently, have all the necessary knowledge and skills in this area. ${ }^{1}$
Currently, the objective necessity of restructuring of construction enterprises is dictated primarily by the following circumstances: physical and moral aging of a part of assets of enterprises; high production costs, lack of financial support of the development of land use and territory planning documents, insufficient administrative support of projects of housing and industrial construction, the impact of excessive administrative procedures hindering the implementation of investment in construction. Under these conditions, the main strategic task of almost all construction enterprises is to preserve sustainable competencies provided by reforming of the organizational structures, as after radical changes in the external environment of operation of construction enterprises, the aims and objectives of the production and economic activity must change accordingly, and, consequently, the material and organizational basis of their management. Restructuring of construction enterprises is characterized by bringing their organizational and production structure in line with volumes of production, for which there is effective demand allowing the optimization

*Author for correspondence 
of the cost/income ratio, ensuring the competitiveness of products and investment attractiveness, which entails changes in the structure of production and management objects. ${ }^{2}$ It should be noted that the main purpose of the restructuring of the meso-level of the national economy is an increase in the competitiveness of the relevant branch of sectoral economic activity of the enterprises for the purpose of its sustainable development.

Restructuring at the micro level is the process of adaptation of the internal structures, such as a construction enterprise, regardless of its scale and legal structure, to the ever-changing conditions of existence and development of the environment in order to achieve greater sustainability of its development and greater economic benefits at the lowest cost.

\section{Method}

In our opinion, the system restructuring affecting all areas of functioning of a construction enterprise may be provided by the organizational and economic mechanism shown in Figure 1.

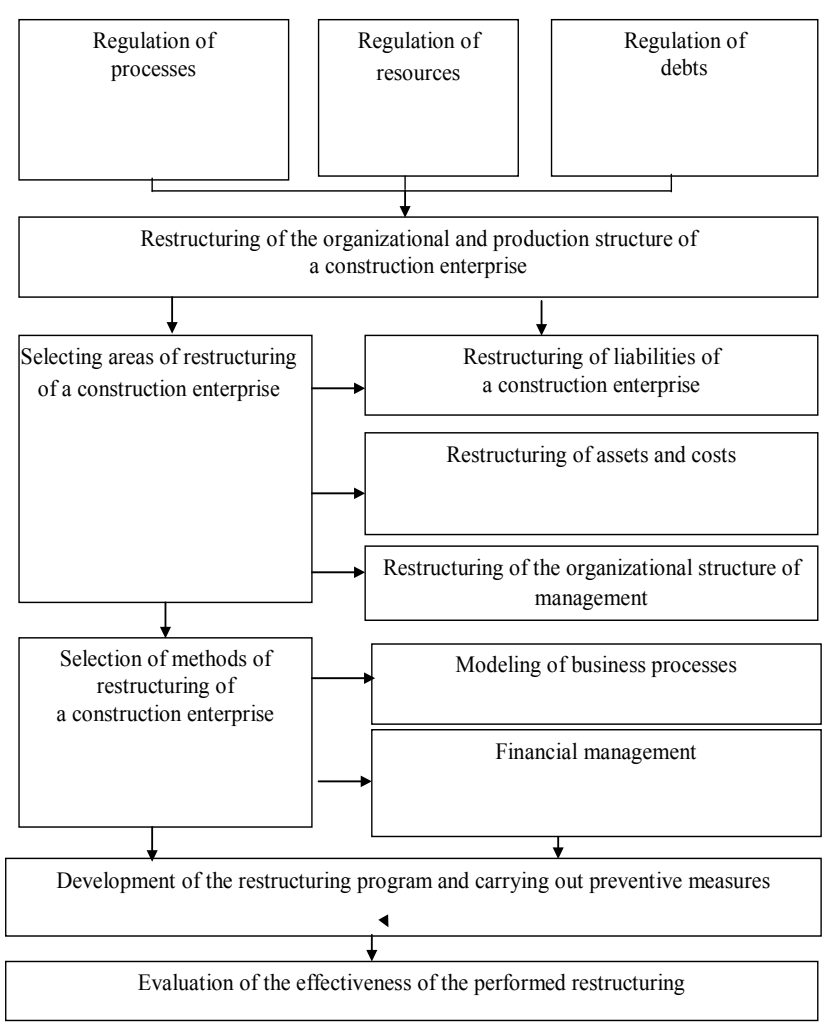

Figure 1. Organizational and economic mechanism of restructuring of a construction enterprise
Restructuring of liabilities involves, first of all, a change in the ownership structure of the construction enterprise in the event of attraction of additional investments; a change in the equity to debt ratio, but without increasing long-term and short-term liabilities, which significantly improves the financial and economic condition in the selection of new sources of financing, forecasting profitability and risk. Equally important in this case is the restructuring of the debt of the construction enterprise providing not only the classical perception of debt restructuring as changes in the maturities and conditions of loans, credits, but any forms of redistribution (including through transfer pricing) of debts among the participants and stakeholders in order to maximize the achievement of management objectives.

Restructuring of assets and costs provides a change in the structure of assets in the balance sheet of the construction enterprise with special attention paid to the structure of investments in subsidiaries and associates, the leasing policy, and the policy of outsourcing.

Restructuring of the organizational and management system usually requires a revision of the organizational structure of management. Selection of the right organizational structure of a construction enterprise adequate to specific conditions is made in accordance with the selected option of restructuring: by activities, by types of objects, by products, by types of customers. Selection of a new organizational structure allows bringing the system of management in accordance with the planned performance levels in a crisis. Of course, linear functional structures are most suitable in the industrial and construction sector, while in the engineering direction, matrix structures with pronounced project orientation prevail. Without a doubt, in the real world it is impossible to give an example of ideal organizational structures; even in the current conditions they are subject to changes and there is no reason to avoid a temporary use of program and target structures in some individual productions, while in engineering departments staff structures are quite appropriate, especially for the preparation of tender proposals, sought after so hard in times of crisis ${ }^{3}$. In our opinion, the selection of directions of restructuring depends on specific internal capabilities and interests of a construction enterprise, as well as on external factors characterizing the situation.

With this consideration in mind, directions of restructuring of construction enterprises can be structured as follows:

Changing the enterprise scale;

Changing the internal structure of the enterprise; 
Changing the ownership structure, capital and corporate control.

Changing the enterprise scale can occur both at its increase and decrease. Increasing the scale (including expansion of the area of activities) of an enterprise as a special type of restructuring may be effected by means of a merger, acquisition, takeover of another enterprise (or several enterprises), by means of consolidation or purchase of the property of another enterprise, by means of creation of a joint enterprise (including foreign participation), by means of purchase of another enterprise or assets of another enterprise, or by means of renting or leasing property.

Reducing the scale of the enterprise can be accomplished by dividing the enterprise into separate financially independent subdivisions, or individual small enterprises, allocation of some services or facilities through the sale of assets of the enterprise, reduction of equity, lease of property, creation of subsidiaries, transfer of assets to another enterprise free of charge or as an offset of obligations, conservation of the property, liquidation of the enterprise or part of its assets. Changing of the internal structure the construction enterprise can be made due to changes in production and organizational structure. This direction requires the enterprise to allocate one or more structural units of the current enterprise on the basis of their assets to create new enterprises. It should be understood that the organizational restructuring is a set of measures aimed at the approximation of the size of enterprise and its subdivisions to the demands of a competitive market environment.

As noted above, changes in the composition and ownership structure, capital and corporate control of enterprises are reflected in changes in the composition and structure of the owners (shareholders, stockholders), which is carried out by conversion of the construction enterprise, its sale or sale of interests or shares. A restructuring program is a tool of implementation of the strategy and tactics of restructuring of a construction enterprise, which is a set of practical and short-term events (Figure 2).

It should be noted that in the development of a restructuring program, one should take into account the specific features of the building production, the specificity of products produced, which is determined largely by the elasticity of demand, the availability of skilled labor force and its cost. The value and prospects of the construction development in connection with the inevitable restructuring should also be taken into account.

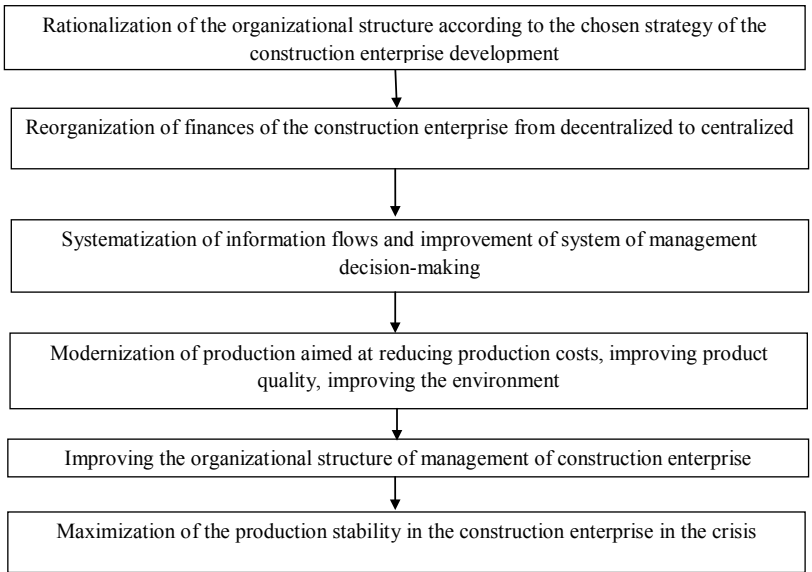

Figure 2. The program of a construction enterprise restructuring

The ability of implementation of specific restructuring procedures without delay, limitations, additional approvals is of particular importance; otherwise, the significance and efficiency of the program implementation become quite irrelevant. It is therefore essential to clearly define the sources, mechanisms of funding and timing of restructuring during the development of a program of the enterprise restructuring.

\section{Results}

Based on these methodological provisions, the program of the construction enterprises restructuring should include:

- Clearly defined objectives and directions of restructuring;

- Procedures and criteria for making decisions on restructuring;

- Methods of restructuring;

- Funds necessary for restructuring and a mechanism of financing;

- Terms of restructuring;

- Activities to stimulate the enterprise restructuring;

- Measures providing social protection of employees of the enterprise;

- Procedures for interaction with local authorities in the course of restructuring;

- Procedures for interaction with the enterprises to be restructured;

- A list of regulatory documents related to the selected method of restructuring. 
We believe that the program should not be aimed at overcoming the resistance, but at changing the direction of the main flow of innovative ideas to the opposite (from bottom to top) and horizontal one (collaboration between subdivisions of the construction enterprise). Then the problem of overcoming goes on the back burner, because people will hardly resist changes planned with their participation. The role of the senior management in this case is to be the creator of a favorable institutional and economic environment rather than to be the designer of innovation.

When involving employees in the process of structural changes, an approach based on the extensive use of the unique advantages obtained by the enterprise relying on team organizational forms can be used. Therewith, target teams (temporary groups) are used both in the development and implementation of the restructuring program (as the subjects of the restructuring process), and as a basic structural cells of the future organization.

Restructuring of even one construction enterprise is a complex, long-term process requiring significant financial and material resources that includes a number of preventive measures (Table 1 ). ${ }^{1}$

Planning preventive measures for the restructuring is the first step in the implementation of the basic procedure for the program development. Preventive measures carried out at the construction enterprise solve the following main issues: reduce the probability of the risk, i.e. the probability of loss of sales; reduce the size of possible damage. ${ }^{3}$ As mentioned above, the restructuring at all levels of production and economic activities of the construction enterprise is contingent upon the need to bringing the internal organization of the economic system to conformity with qualitatively changed environmental conditions of its life (adaptation). However, it is effective only in the presence of other factors, such as more sophisticated marketing, significant investments and appropriate governmental policies. The last item is particularly important, because, as the experience of many countries shows, restructuring carried out in an unstable political environment does not lead to the rise of productivity.

The environment, in which construction enterprises operate, should provide incentives for restructuring in the right direction and an essential element of this environment are the perceived signals of the market. In order to generate an efficient restructuring, conducive to increase of productivity, the market signals should simultaneously reflect the relative costs of different types of economic activity and be sufficiently stable.
Table 1. The sequence of restructuring preventive measures at the construction enterprise

\begin{tabular}{|c|c|c|}
\hline $\begin{array}{c}\text { Stage } \\
\text { No. }\end{array}$ & $\begin{array}{c}\text { Stage description } \\
1 .\end{array}$ & $\begin{array}{c}\text { Arrangement of } \\
\text { commodity markets } \\
\text { and formation } \\
\text { of cooperative } \\
\text { relationships } \\
\text { evaluation of the technical } \\
\text { level and competitiveness of } \\
\text { products; identification of } \\
\text { available production capacities } \\
\text { and volume of the actual and } \\
\text { potential effective demand at } \\
\text { domestic and foreign markets }\end{array}$ \\
\hline 2. & $\begin{array}{c}\text { Enterprise debt } \\
\text { restructuring }\end{array}$ & $\begin{array}{c}\text { analysis of the financial } \\
\text { condition of the enterprise, } \\
\text { analysis of the structure and } \\
\text { dynamics of accounts payable } \\
\text { and receivable }\end{array}$ \\
\hline 3. & $\begin{array}{c}\text { Restructuring of } \\
\text { production activities }\end{array}$ & $\begin{array}{c}\text { analysis of the structure of } \\
\text { costs and identification of } \\
\text { reserves to reduce them } \\
\text { (especially fixed costs } \\
\text { determining the level of } \\
\text { business risk); introduction of } \\
\text { advanced technologies }\end{array}$ \\
\hline 4. & Fund raising & $\begin{array}{c}\text { long-term capital investment } \\
\text { of private and foreign } \\
\text { investors; growth of equity }\end{array}$ \\
\hline
\end{tabular}

In a well-functioning economy market, signals reflected in the performance (volume of sales, production cost, profitability, etc.) are the indicators stimulating most of the restructured units, the process of which is initiated, as a rule, by top managers or the board of directors of the construction company or enterprise.

For this reason, the depth and extent of the restructuring may be different:

- Partial restructuring covering certain aspects of the activities of a construction enterprise or only one of them (restructuring of capital, changes in organizational structure, control systems and other);

- Global or radical restructuring covering all or almost all spheres of economic activity of the construction enterprise ensuring its transition to the next level.

The restructuring effect is limited in time. Depending on its depth and size, as well as external and internal conditions of functioning of the enterprise, it may vary over a fairly wide range (typically 2-3 to 6-8 years). With this consideration in mind, partial, limited restructuring, which is often very effective, not only should be opposed 
to a global one, but, on the contrary, can be regarded as a certain stage, phase of a broader restructuring.

The following features of restructuring are the most common, although not covering its objectives: development and introduction of new products; strengthening of the competitive position; overcoming the crisis, restoring solvency and financial stability. Therefore, not only the obvious crisis processes are an incentive for the construction enterprise restructuring, but also the desire to strengthen its competitive position in the target market. Proper restructuring provides a construction enterprise with obvious advantages over its competitors.

Restructuring of construction enterprises may take the form of:

a) Structural reforms;

b) Institutional reforms (institutions, domestic laws).

Structural changes in enterprises involve the formation of subdivisions:

1) Budgetary and self-supporting units (traditional management departments);

2) Financial responsibility centers (cost, revenue, profits, investments centers);

3) Subsidiaries and affiliates.

The whole complex of measures for the restructuring of construction enterprises must be implemented by innovative managers working in close cooperation with each other and with the leadership. From the methodological point of view, we have proposed two alternative ways of cross-functional solution of problems arising at that:

To use a formal structure (group) for the formulation of the problem, analysis and collection of data on it, development and testing of possible alternative solutions before coming to a final decision (this method is relatively safe in terms of risk);

To apply a systematic approach to the business process reengineering (when selecting this method, one should take into account the risks, hazards and major mistakes in the implementation of such a radical approach, especially if it is used as a tool for development of the construction enterprise or the whole improvement process).

The second method involves identification of new business processes in accordance with uniform principles (e.g. on the basis of the product quality assurance method), statement of the mission of the fundamental objectives of the enterprise activity, formulation of the mission of subdivisions or units, as well as a list of key success factors necessary and sufficient to achieve the mission target. Considering the specificity of two-level restructuring of a construction enterprise, it should be noted that the process should not be limited only to these two levels. They are regarded as a priority, while the possibility of restructuring at the level of any structural segment, as well as at the level of separate subdivisions of concrete construction enterprises are possible. It is much more important to see the consistent relationship of different types of restructuring and hold it in a certain consistent direction, for example: from the restructuring of investments to the restructuring of core assets, further to the restructuring of business processes, and only then to the restructuring of the organizational structure.

The restructuring of business processes is a purposeful activity involving an analysis of processes in the structure of the construction enterprise, identification of bottlenecks and building effective chains of operations within the processes. The restructuring is carried out by component wise decomposition of processes into simple operations subject to a thorough analysis of the efficiency by forming process effectiveness criteria and operations for their optimization.

The introduction of new business processes is an organizational transformation, the most important aspect of which is the implementation of new management solutions. For that end, we propose the use of the following methodological approach to the management of organizational changes occurring in the course of restructuring: the improvement of business processes occurring in response to the successive exposure to the external environment, or in response to unsatisfactory performance in management of the construction enterprise by means of incremental accumulation of successive changes, which result in the transformation of the structure of business processes over a long period.

The target model of the business process involves not only the development of a scheme and its basic characteristics, but also the target level of "maturity" (i.e. manageability and organization). There is a number of methods to build it, one of which is the SMM technique developed by experts of the Software Engineering Institute (Carnegie Mellon University), which was originally designed to improve the business processes of the development and maintenance of software, but later was adapted to different subject areas of activity. ${ }^{4}$ The model has five levels of process maturity. In an ascending order of maturity, these are: initial, recurring, specific, 
manageable and optimized levels. The characteristics of each level are shown in Table 2.

When restructuring, the transition from one level to another is accompanied by certain activities, provided that it is impossible to skip the maturity levels, as such a task is fraught with failure and decrease in the maturity level. Each maturity level has its key areas of activity, which in turn have common features containing the key approaches to increasing maturity. ${ }^{5}$

The main advantages of the proposed approach are the use of a modular approach to business process management, on the basis of which the work to improve the business process is divided into modules (multiple processes), and at the end of one module (improvement of several processes) the next one begins; resistance at the beginning of the business processes is minimized and then monitored during the implementation of reforms; the external constraints and the internal capabilities of the enterprise are balanced. At the same time, the functional subdivisions are transformed into the process teams focused on the release of a product(s) and on a particular consumer.

In accordance with this, the management of the restructured construction enterprise should proceed on two subordinate levels-executive and coordinative (Figure 3).

The upper level of management is provided by the general manager-the coordinator of business process teams and the information and analytical center. For a large construction enterprise (company), it is advisable to introduce deputy managers to coordinate the work of allocated business process teams. Therefore, business process teams themselves can find potential customers and ensure the best fulfillment of their requests. An alternative approach may be to put sales into a separate business process.

An obligatory element of such a concise vertical of management should serve the board of managers of business process teams. Its main function will be the elaboration of a development strategy for the construction enterprise, in particular, direction of investments for the expansion of activities, formation of a reserve fund, diversification of the production. At the same time, the powers for distribution of funds between the board of managers as the administrative authority and the board of directors representing the interests of shareholders should by strictly delimited.

If the composition and content of the business processes do not provide the required adaptation to
Table 2. Behavioral characteristics of levels of business processes' maturity

\begin{tabular}{|c|c|}
\hline $\begin{array}{c}\text { Maturity } \\
\text { level }\end{array}$ & Behavioral characteristics \\
\hline Initial & $\begin{array}{c}\text { Random and chaotic order of actions for the } \\
\text { implementation of business processes. }\end{array}$ \\
\hline Recurring & $\begin{array}{c}\text { Principles of business processes have been } \\
\text { established. There is a repeatability of the } \\
\text { logic of business processes. }\end{array}$ \\
\hline Specific & $\begin{array}{c}\text { Business process is documented in detail, and } \\
\text { supported by the leadership. Responsibilities } \\
\text { are clearly defined, control mechanisms } \\
\text { including criteria for the implementation of } \\
\text { actions are defined and implemented. }\end{array}$ \\
\hline Manageable & $\begin{array}{c}\text { Objectives of business processes are achieved } \\
\text { with a high probability. Business processes are } \\
\text { absolutely predictable. }\end{array}$ \\
\hline Optimized & $\begin{array}{c}\text { Permanent work to improve the methods of } \\
\text { business processes management is carried out. }\end{array}$ \\
\hline
\end{tabular}

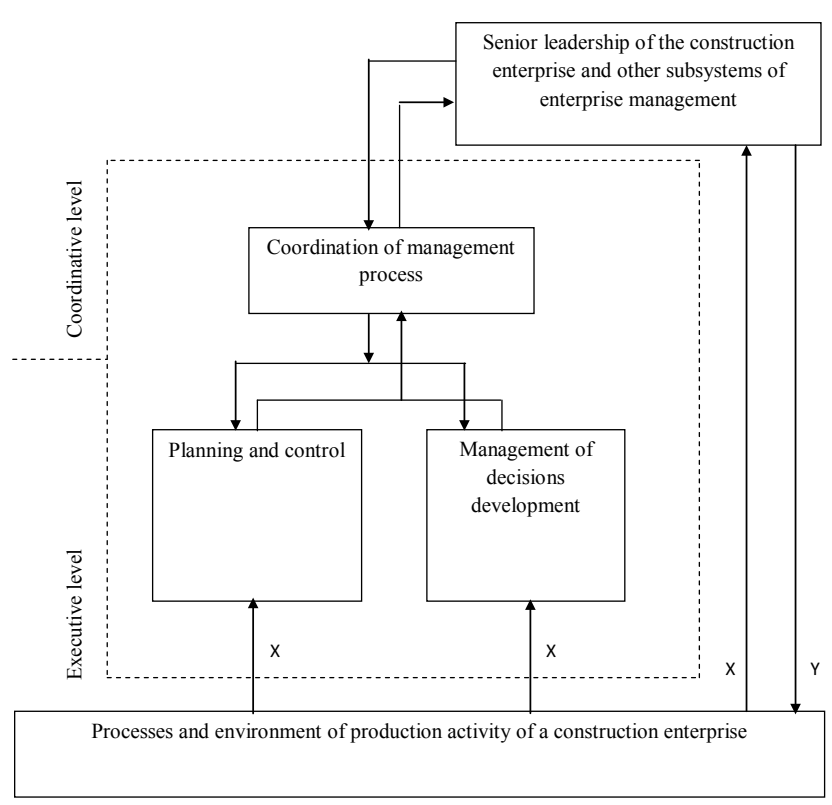

Figure 3. Organizational structure of management of the restructured enterprise (X - controlled variables, Y- controlling actions)

changing competitive internal and external environment of the construction enterprise, there is a progressive decline in value resulting in a loss of the competitive position, i.e. in a crisis. As practice shows, the beginning of crisis developments is the absence of purposeful actions on the part of the management of the construction enterprise aimed at the development of a management strategy. ${ }^{6}$ 
The existing decision-making system has the largest impact among the in-house institutes of restructuring of a construction enterprise. Managerial decisions are a creative act of the subject of management, determining the program of activities to achieve the collective goal with the least expenditures of labor and financial resources on the basis of the knowledge of objective conditions for the functioning of the managed object and an analysis of the necessary information. Development of effective solutions is a fundamental prerequisite for ensuring the competitiveness of a construction enterprise. It involves at least:

- Creation of an effective team of professional managers;

- Formation of organizational structures;

- Conducting proper personnel policies;

- Regulation of socio-economic and psychological relationships at the enterprise;

- Creation of a positive image of the company and others.

\section{Discussion}

Making managerial decisions on the restructuring is a kind of professional responsible work of the senior leaders, namely their use of power associated with certain actions of subordinates to achieve the posed operating task. Typically, this is a selection of the best possible solution. Optimality in managerial decisions on restructuring is an important factor in improving the competitiveness of a construction enterprise. In the preparation of a managerial decision, inerrancy, completeness and timeliness of the necessary information play an important role. It must meet high demands. Clarity of the task assignment, data analysis, efficiency of processing of the results depend on the qualifications of the personnel and applied technologies and work processes. An effective head of a construction enterprise has to understand the interdependence of decisions and choose the alternatives that make the greatest contribution to improving the competitiveness of products. A decision is sometimes fraught with compromises, difficulties, dangerous consequences and side effects, the importance of which must be anticipated by the manager, and he must be prepared to take appropriate actions. There is always a shortage of reliable and comprehensive information in situations of making unique decisions, which can be regained only through practical experience and a detailed study of possible hypotheses. The main source of information for the evaluation of alternatives to the proposed managerial decisions is the professionalism of experts and decisionmakers in the hierarchy of their duties and powers in the management structure of the construction enterprise. In real situations, the head is required to have such qualities as the art of situation analysis, deep professional knowledge of decision-making techniques and methods, the ability to provide evidential reasoning, professional skills in management, sufficient knowledge of the economy and organization of work and, of course, management in the process of making managerial decisions.

In practice, the best solution to a problem is associated with a new look at it, i.e. a search for new alternatives. Accordingly, there are the following stages of evaluating alternatives:

- Clarification of objectives and selection of a target;

- Specification of alternatives;

- Analysis of alternatives;

- Selection of the best solution;

- Presentation of results.

- Five logical steps can be distinguished in the approach involving an analysis of systems and operations:

- Allocation of the objective or a set of objectives;

- Allocation of alternative means of achieving the objectives;

- Identification of resources for each system;

- Construction of a mathematical model (in the approach of operations analysis) or a logical model, i.e. a number of dependencies between objectives, alternative means of achieving them, environment and resources;

- Definition of criteria for selecting the preferred alternative.

Thus, the proposed approach to the restructuring of a construction enterprise is connected particularly with the allocation of the system from the external environment and identification of a set of consistent, logical steps ensuring retention of competitive advantages. As can be seen from Table 3, certain stages of decision-making meet certain methods for their solution (Mazur, 2001).

In practice, few managerial decisions turn out to be purely programmable, many decisions require a creative, individual approach. Development of the most efficient ways of building control systems of a restructured enterprise is an important component of the project to re-engineer the business processes, or the whole process of improving the organizational forms of management. 
Table 3. Actions by stages of the managerial decision-making process

\begin{tabular}{|c|c|c|}
\hline $\begin{array}{l}\text { Stages ofthe } \\
\text { decision- } \\
\text { making } \\
\text { process }\end{array}$ & & Actions \\
\hline \multirow{2}{*}{$\begin{array}{l}\text { Preparation } \\
\text { and analysis } \\
\text { of data }\end{array}$} & $\begin{array}{l}\text { Receipt and } \\
\text { preparation of } \\
\text { data }\end{array}$ & $\begin{array}{l}\text { - surveillance and search } \\
\text { - receipt and perception of } \\
\text { data } \\
\text { - filtering and collective } \\
\text { presentation of data } \\
\text { - identification of the situation } \\
\text { - problem statement }\end{array}$ \\
\hline & $\begin{array}{l}\text { Formulation } \\
\text { of the } \\
\text { problem } \\
\text { situation }\end{array}$ & $\begin{array}{l}\text { - identification of the problem } \\
\text { situation } \\
\text { - identification of the } \\
\text { structure of the problem } \\
\text { situation }\end{array}$ \\
\hline \multirow{4}{*}{$\begin{array}{c}\text { Task } \\
\text { assignment } \\
\text { and } \\
\text { development } \\
\text { of } \\
\text { alternatives }\end{array}$} & $\begin{array}{c}\text { Task } \\
\text { assignment }\end{array}$ & $\begin{array}{l}\text { - classification of the factors } \\
\text { defining the objectives, } \\
\text { criteria, } \\
\text { - determination of conditions } \\
\text { - coordination and evaluation } \\
\text { of the components of the } \\
\text { problem } \\
\text { - formulation of the problem }\end{array}$ \\
\hline & $\begin{array}{l}\text { Development } \\
\text { of models and } \\
\text { methods of } \\
\text { decision }\end{array}$ & $\begin{array}{l}\text { - development of a model for } \\
\text { solving the problem } \\
\text { - search development and } \\
\text { selection of procedures for } \\
\text { the solution of problem }\end{array}$ \\
\hline & $\begin{array}{l}\text { Development } \\
\text { of alternatives }\end{array}$ & $\begin{array}{l}\text { - development of alternatives } \\
\text { - grouping of alternatives by } \\
\text { the objectives (criteria) and } \\
\text { conditions (resources) }\end{array}$ \\
\hline & $\begin{array}{l}\text { Prediction } \\
\quad \text { and } \\
\text { evaluation }\end{array}$ & $\begin{array}{l}\text { - prediction and evaluation of } \\
\text { alternatives } \\
\text { - forecast and evaluation } \\
\text { of impacts of alternatives } \\
\text { implementation }\end{array}$ \\
\hline \multirow{3}{*}{$\begin{array}{l}\text { Taking a } \\
\text { decision on } \\
\text { restructuring }\end{array}$} & $\begin{array}{l}\text { Determining } \\
\text { (specification) } \\
\text { of selection } \\
\text { criteria }\end{array}$ & $\begin{array}{l}\text { - determination of private } \\
\text { alternatives and/or profiles } \\
\text { of preferences and selection } \\
\text { of alternatives } \\
\text { - generalization of } \\
\text { manifestation of criteria } \\
\text { and/or profiles of } \\
\text { preferences and selection of } \\
\text { alternatives }\end{array}$ \\
\hline & Selection & - selection of criteria \\
\hline & $\begin{array}{l}\text { Execution of } \\
\text { decisions }\end{array}$ & $\begin{array}{l}\text { - interpretation and } \\
\text { evaluation of results of } \\
\text { choice (decision) } \\
\text { - development and } \\
\text { issuing directives for the } \\
\text { implementation of decision }\end{array}$ \\
\hline
\end{tabular}

\section{Conclusion}

Thus, restructuring of construction enterprises is not only a mechanism for neutralizing the negative effects of the crisis in construction, but also an objectively necessary process implementing the concept of competitiveness management in practice.

Strategic restructuring should ensure sustainable competitive advantages for the long term development of the construction company, which are formed and fixed in the developed managerial decisions ensuring an adequate response to changes in the external and internal competitive environment of the construction business.

Tactic restructuring is advisable in the operating management of a construction enterprise, and its content should be determined by the degree of conformity of characteristics of the construction enterprise with the needs of contractors and potential buyers.

The process of managing a restructured construction enterprise should proceed on two subordinate levels-executive and coordinative, which makes it possible to use a modular approach to the management of business processes resulting in a drastic decrease in the vertical and expansion of the horizontal range of management, implementation of a system of monitoring the performance of the construction enterprise and adoption of optimal solutions on this basis.

\section{Acknowledgments}

This article was prepared within the framework of the Government order of the Ministry of Education and Science of the Russian Federation "Development of an Organizational and Economic Mechanism for the Effective Development of Economic Sectors" implemented by FSBEI HPE "Dagestan State Technical University". Special thanks to the reviewers of the scientific article.

\section{References}

1. Van Home JC, Vahovich JM. Osnovyfinansovogomenedzhmenta [Fundamentals of Financial Management] $\left(12^{\text {th }}\right.$ ed., Translated from English). Moscow: I.D. Williams, LLC; 2006. [in Russian].

2. Mazur II, Shapiro VD. Restrukturizatsiiapredpriiatiii kompanii [Restructuring of enterprises and companies] (Ed., Mazur II). Moscow: Publishing house Economy, CJSC; 2001. [in Russian]. 
3. Kleiner G. Promyshlennaiarestrukturizatsiiakaksredstvous ileniianatsionalnoikonkurentosposobnosti[Industrial restructuring as a means to enhance national competitiveness]. Problemyteoriiipraktikiupravleniia [Problems of Management Theory and Practice]. 2002; 4:17-25. [in Russian].

4. Zucchi F, Edwards S. Human resource management aspects of business process reengineering: A survey. Business Process Management. 1999; 5(4): 325-44.

5. Esetova AM, Magomedov HM-M, Hamidov TA. Sistemnyipodkhod k upravleniiukonkurentnympotentsialom stroitel'nogopredpriiatiia [Systematic approach to the management of competitive potential of the construction enterprise]. TransportnoedeloRossii [Transportation Business in Russia, Special Edition]. 2006; 11(Part I):37-40. [in Russian].

6. Esetova AM. Metodicheskiepodkhody k upravleniiustrategicheskoikonkurento-sposobnost'iustroitelnogopredpr iiatiia [Methodological approaches to the management of strategic competitiveness of the construction enterprise]. Problemysovremennoiekonomiki [Problems of Modern Economy]. 2008; 1(25):190-3. [in Russian]. 